\title{
Survey of recreational use of The Las Kabacki forest nature reserve in Warsaw (Poland)
}

\begin{abstract}
This paper discusses recreational use of protected land with the example of Las Kabacki, a forest located in the southern part of Warsaw, in the vicinity of the district of Ursynów. The area has been excluded from traditional forest cultivation since 1938. From 1980 onwards it has enjoyed the status of a reserve due to its natural resources and scenic attributes. Highly developed and densely populated residential areas (NatolinWyżyny and Kabaty) lie adjacent to the northern border of the forest. For their inhabitants, Las Kabacki is a key recreational area. This results in a functional and spatial conflict of interests between nature protection objectives on the one hand and the recreational needs of inhabitants on the other hand. To find the answer to the question of how to match the interests of a natural reserve with leisure requirements, users of Las Kabacki were asked for their opinions regarding the following issues: the natural values of the reserve and their perception, forms of preferred recreational behaviour in the reserve, awareness of threats to the natural environment in the reserve arising from anthropogenic pressure, readiness to resign from preferred forms of leisure in favour of protecting nature, and possibilities for eliminating the conflict of interests between the recreational use of the reserve and protection of its natural values. Also, two SWOT analyses were carried out aimed at determining a nature conservation strategy in the reserve as well as its leisure use.
\end{abstract}

Keywords

Nature reserve $\cdot$ Las Kabacki forest $\bullet$ SWOT analysis $\cdot$ leisure

(c) University of Warsaw - Faculty of Geography and Regional Studies

\section{Introduction}

In an urban landscape, green areas are the key leisure facility for inhabitants, providing them with opportunities to relax and observe wildlife. With relevant infrastructure in place, these areas facilitate sport activities, ensuring mental and physical well-being. Sometimes they are a source of inspiration for artists. Without contact with nature, people become depressed, and the quality of their life deteriorates (Oleksiejuk, Jankowska 2009, Bożętka 2008, Chmielewski et al. 1996, Piatkowska 1983). This opinion is a part of the biophilia hypothesis developed by Edward O. Wilson (1984).

The recreational use of protected areas, including open land reserves, has been discussed in several publications (Seeland et al. 2002, de Vries, Goossen 2002, Shaw, Reeve 2008, Pigram, Jenkins 2006, Hall \& Page, Faggi et al. 2011, Borgsröm 2012, Jarošik et al. 2011). This is an important topic, especially for urban areas, because the formal function of a nature reserve is to protect, with other functions considered secondary and subordinate to the key one, therefore pursued only to the extent of not posing a threat to the natural balance.

Urban nature reserves constitute a special class of green areas, since they include "...areas in their primary condition, unchanged or little changed, ecosystems, sanctuaries and habitats for plants, animals and unanimated objects with special natural, scientific, cultural or scenic values" (Nature Conservation Act of 16 April 2004, Article 13.1). Their key role is to protect,

\author{
Ewa Malinowska ${ }^{1}$ \\ Iwona Szumacher ${ }^{2}$ \\ ${ }^{1}$ Institute of Physical Geography, \\ Faculty of Geography and Regional Studies, \\ University of Warsaw \\ e-mail: emal@uw.edu.pl \\ 2Institute of Physical Geography, \\ Faculty of Geography and Regional Studies, \\ University of Warsaw \\ e-mail: szumi@uw.edu.pl \\ Received: 18 March 2013 \\ Accepted: 4 June 2013
}

along with two others - scientific and educational - which are subordinate. Nature reserves, like other protected areas (e.g. forests, places with outstanding vegetation or scenic features), hold a special position in highly anthropogenic urban spaces, where they create islands of valuable natural and semi-natural landscape. It is worth noting, though, that the natural value underlying the decision to preserve a piece of land is not always an absolute criterion. A similar plot of land situated outside an urban area would likely never obtain protected status, or the form of protection would be different from in the city. This is the case with old river beds or woods which are the remains of ancient forests, river islands or shoals.

Most Polish cities have up to five reserves, occupying about 300 hectares of space. Warsaw is an exception with its twelve reserves occupying nearly 3,000 ha (Table 1). Seven are made accessible to hikers and bikers, while access to the others is restricted for administrative, ecological or safety reasons.

Their location in proximity to human settlements and roads means that people treat them mostly as recreational areas, just another type of grassland. This is the case for open reserves equipped with leisure infrastructure (huts, camping places, playgrounds, hiking and biking routes, beaches, swimming places, small bars etc.), as well as national heritage areas. 
Table 1. Number and area of nature reserves in province capitals (source: General Directorate for Environmental Protection)

\begin{tabular}{|c|c|c|c|}
\hline City & Number of reserves & Protected area (ha) & What is protected \\
\hline Warsaw & $\mathbf{1 2}$ & $\mathbf{2 , 8 5 0}$ & landscape, vegetation, animals, forest \\
\hline Gdańsk & 5 & 270 & forest, vegetation, animals \\
\hline Kielce & 5 & 59 & forest, unanimated objects \\
\hline Kraków & 5 & 49 & forest \\
\hline Białystok & 3 & 105 & landscape, animals, forest, unanimated objects \\
\hline Łódź & 2 & 79 & forest \\
\hline Szczecin & 2 & 223 & peat bog \\
\hline Katowice & 2 & 129 & vegetation \\
\hline Olsztyn & 2 & 18 & forest \\
\hline Toruń & 1 & 32 & forest \\
\hline Lublin & 1 & 24 & 8 \\
\hline Rzeszów & 1 & & \\
\hline
\end{tabular}

In light of the Nature Conservation Act, though, barbecues, hiking, biking, skiing and horse riding are forbidden except for designated and marked routes. The ban also includes water sports, use of motor boats and other motor vehicles, swimming, sailing, organizing events, entry of dogs and camping (except for designated places), as well as many other things ${ }^{1}$, which for many people are a prerequisite for good-quality relaxation.

The above restrictions arising from the necessity to protect areas of high natural value further reduce the frugal recreational resources available in urban areas, with demand remaining much higher than supply. This results in a functional and spatial conflict of interests between nature protection objectives on the one hand and the recreational needs of inhabitants on the other hand. As a result, none of the roles assigned to reserves are performed in the correct or sufficient manner.

This gives rise to the following questions:

- Is it possible to match the interests of natural reserves with leisure?

- Does leisure always mean causing detriment to nature conservation objectives and vice versa?

- Is nature conservation as established by the law effective enough to prevent anthropogenic pressure?

- Can nature reserves survive in urban spaces?

To answer these questions, it is necessary to monitor the quality of environmental components and natural values and, if necessary, verify the viability of the reserve as a form of protection for the entire area, since external and internal threats might have irreversibly damaged the natural value of the protected spot. Furthermore, a program for reshaping and revitalizing the environment (if changes are reversible) should be developed, as well as a recreational concept, if such a form of usage is supported by the administrative decision. In other words, a consistent, comprehensive strategy should be generated to manage the two adverse aspects of land use and be included in

${ }^{1}$ Art. 15. 5 of the Nature Conservation Act of 16 April 2004: "...the Director General in charge of nature protection, in liaison with a regional director in charge of nature protection, may permit departure from restrictions binding in a nature reserve, (...) if the departure is justified with (...) tourist, recreational or sport purposes and shall not negatively impact the objectives of the reserve..." the Protection Plan. Unfortunately, as observed in Warsaw, urban nature reserves (even old ones) either have no protection plans developed $^{2}$ (except for one), or these plans are still in the initial stages of preparation. Therefore, no concept of their protection and rational use exists.

\section{Research objective}

Nearly all of the problems described above, with particular focus on conflict of interests, can be observed in the forest called Las Kabacki im. Stefana Starzyńskiego located in the southern part of Warsaw, in the district of Ursynów. This 902.68 ha area was classified as a nature reserve in $1980^{3}$ due to its natural and scenic values. The reserve includes the Warsaw Escarpment with its deciduous forest (of the Carpinetum type - Chojnicki 1991), a remnant of the Old Mazovian Forest. Changes in the species structure of the forest arising from the invasion of pine and foreign species in the canopy and understory (Prunus serotina, Robinia pseudoacacia L., Quercus rubra L., Acer negundo L.) made its composition not fully compatible with the endemic plant communities, thus necessitating renaturalisation or remodelling (Fig. 1).

Old pines mixed with larch and oak (up to 130 years old), growing on brown and sandy soils, are the most valuable components of the plant community. The entire reserve is under active protection except for a small spot in the eastern part of the forest, where only the landscape is protected. The Las Kabacki Reserve contributes to the regime underlying the Natural System of Warsaw (Opracowanie ekofizjograficzne ... 2006, Rogowska 2003, Dabrowski 2004, Malinowska, Szumacher 2008). Its area has been classified as playing a predominantly biological role due to the presence of multi-species plant communities.

Las Kabacki has no buffer zone, a project (Fig. 1 i 2) dating only from 2010, when the Protection Plan (Plan ochrony... 2010) was being developed, i.e. 30 years after the reserve was established. Therefore, the presence of family houses and arable land in the buffer zone is not surprising, and undermines its protective

In mid-2012, the Kępy Zawadowskie Reserve had an approved protection plan. For Las Kabacki, the plan is ready, while for other reserves, the plans are still in preparation or do not exist at all.

${ }^{3}$ Ordinance of the Minister of Forestry and Wood Industry of 11 August 1980. 


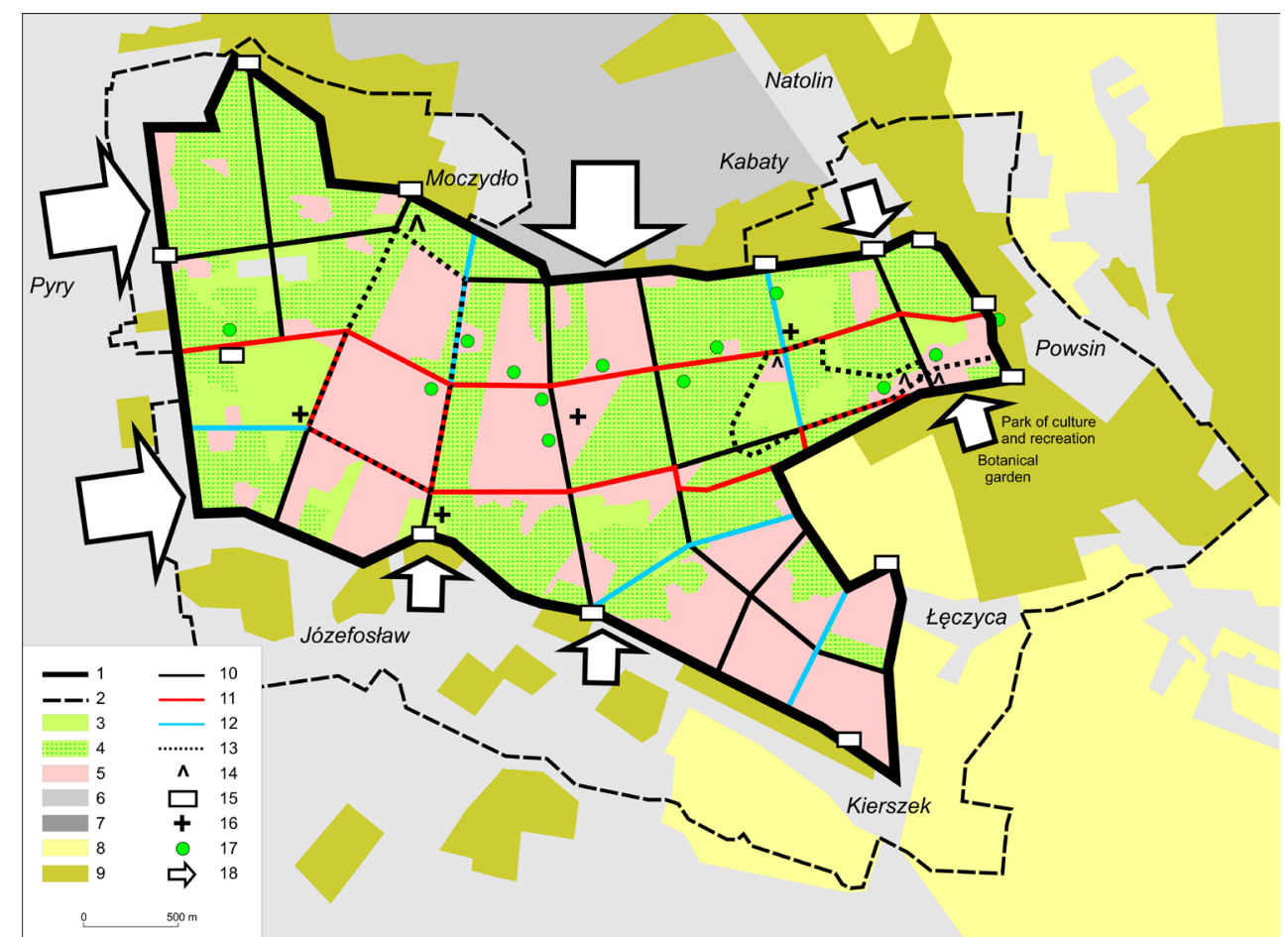

Fig. 1. Recreational infrastructure, internal and external threats in the Las Kabacki Reserve (source: Protection Plan for "Las Kabacki im. Stefana Starzyńskiego" Reserve - Project, own research). Legend: 1. limit of the Las Kabacki Reserve, 2. limit of the proposed buffer zone, 3. forest community with natural species composition, 4. forest community partially compliant with natural species composition, 5. forest community not compliant with natural species composition, 6. detached, low-rise single-family houses or densification of low-rise single-family home areas, 7. high-rise buildings, 8. agricultural land, 9. biologically active areas, 10. pedestrian and bicycle path, 11. tourist trails, 12. footpath, 13. educational trails, 14. shelters, huts, 15. information boards, 16. historical monuments, 17. natural monuments, 18. increased anthropopressure

function. The forest is surrounded by residential areas (NatolinWyżyny and Kabaty with apartment buildings to the north, family house settlements in Pyry, Dąbrówka and Józefosław to the west and south). To the east and south-east, it lies adjacent to a large 50-hectare park (Park Kultury in Powsin) and the Botanic Garden of the Polish Academy of Science, frequented by city inhabitants.

The reserve has six entries, these being in fact extensions of streets leading from the adjacent residential areas (Fig. 1). In practice, the forest is easily accessible from any side, since there are no natural barriers that would in any way direct pedestrians or bikers to specific points on its borders.

Research carried out for the purpose of the Protection Plan (Plan ochrony... 2010) indicated that on non-working days with fine weather the forest is visited by approx. 2,000 pedestrians and 4,800 bikers. On working days, the number drops by approx. 80 percent. The large crowd of people entering the reserve every day and moving around it poses a threat to the wildlife. The most harmful behaviours include walking off the routes, having barbecues, building shacks, piling dirt, digging holes, using old wood to make fire, tearing bark off trees, walking dogs, throwing waste, making noise, etc. This results in a number of disadvantageous changes to the forest environment - in particular the devastation of soil, litter, scaring wild animals, waste piles and constitutes a flagrant breach of the cited Article 15.1 of the 2004 Nature Conservation Act determining behaviour allowed in nature reserves.

The Protection Plan developed in 2010 for the Las Kabacki Reserve provides a detailed account of internal and external threats (Fig. 1) and preventive measures (Fig. 2). Its authors focus on transforming and renaturalising the plant communities (Fig. 2) and regulating water conditions, with less attention paid to anthropogenic pressure related to leisure, despite the clear negative changes caused by this factor. They even allow leisure activities in the forest with the following restrictions:

- Limiting possibilities to move off the official routes by blocking illegal paths with natural barriers (logs),

- Establishing a buffer zone around the reserve and determining routes that would link it to other eco-corridors,

- Retaining some people in the buffer zone through provision of suitable leisure places (the park to the north, development of Polana Śródleśna as a leisure area),

- Including nature protection issues arising in the reserve (noise, waste, dogs) on the education curriculum for schools operating in adjacent areas,

- Educating people in the reserve through information boards,

- Regular cleaning and waste disposal.

Some of the proposed measures (directing the traffic, limiting illegal access) have been attempted for some time and have proven ineffective, while others cannot be implemented since the buffer zone has not been formally designated or supported with relevant provisions in the local spatial plans. The measures regarding education will provide some outcome in several years (if implemented at all). The Protection Plan in fact accepts the current status, lacking any sustainable or effective solutions for the conflict of interests involving the protection of wildlife and the recreational needs of people living in the proximity of the forest. 


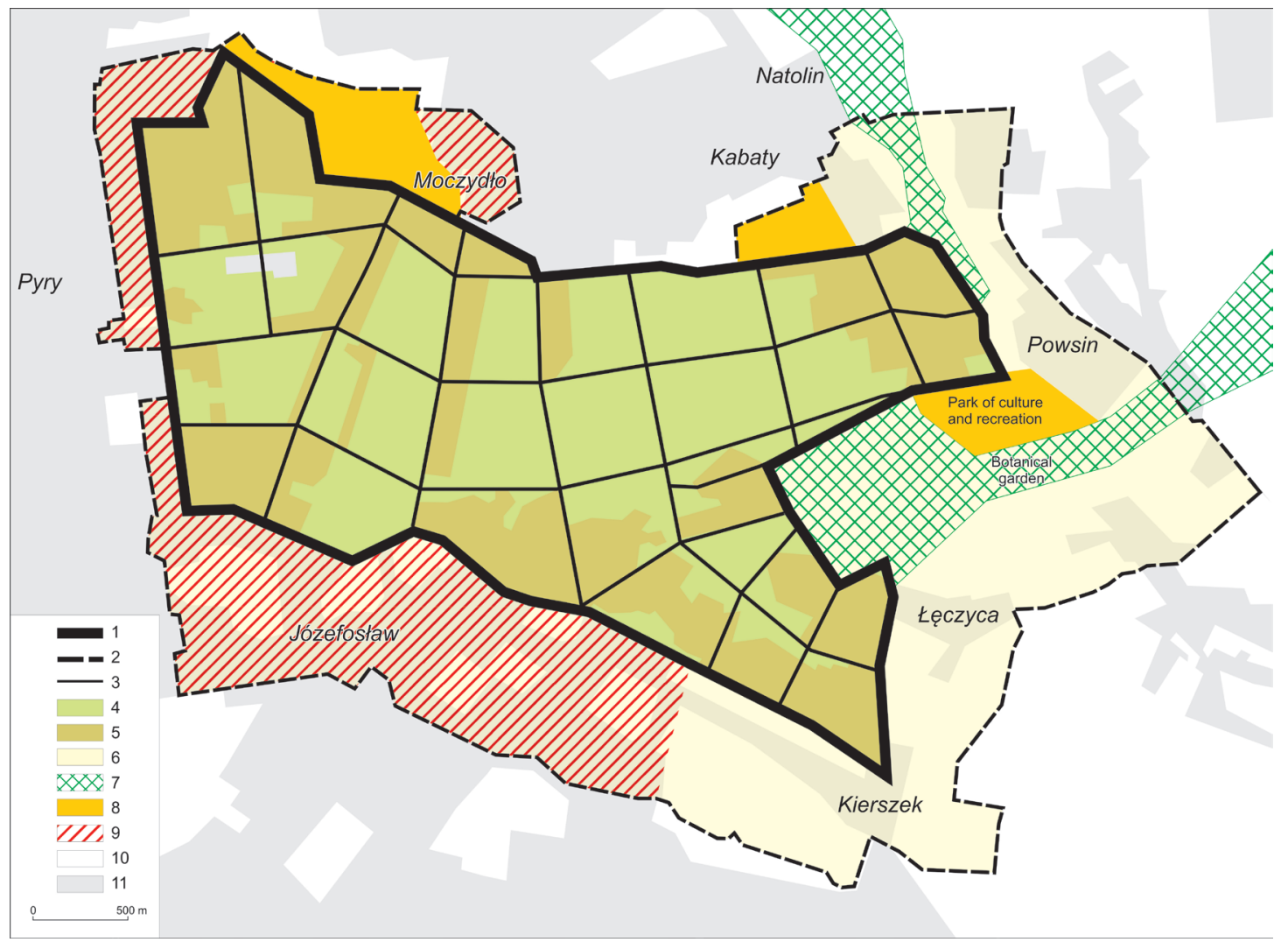

Fig. 2. Counteracting environment degradation and threats in the Las Kabacki Reserve (based on the draft Protection Plan for the "Las Kabacki im. Stefana Starzyńskiego" Reserve and own research). Legend: 1. limit of the Las Kabacki Reserve, 2. limit of the proposed buffer zone, 3. main roads and trails, 4. forest community not protected, 5. forest community with tree stand revitalization, 6. buffer zone of the reserve, 7. ecological corridors - project, 8. area with existing and proposed recreational infrastructure, 9. limited functioning of the buffer zone, 10. biologically active areas outside the buffer zone, 11. built-up area

\section{Research methods}

The opinion of visitors is also important to find the answer to the question of how to match the interests of natural reserves with leisure needs. The scope of our research, carried out since 2009 and based on a questionnaire and direct interviews, was to learn the opinions of users of Las Kabacki regarding the following issues:

- Natural values of the reserve and their perception;

- Forms of preferred recreational behaviour in the reserve;

- Awareness of threats to the natural environment in the reserve arising from anthropogenic pressure;

- Readiness to resign from preferred forms of leisure in favour of nature protection;

- Possibilities to eliminate the conflict of interests between the recreational use of the reserve and protection of its natural values.

The research was carried out in the period from May to October, when the traffic peak occurs in the reserve. The questionnaire included a total of 298 randomly selected individuals met in the Las Kabacki forest and representing various age groups, while direct interviews included a group of 43 randomly selected respondents.

In the years 2011-2012, analyses and assessments were carried out aimed at determining the nature protection strategy in the reserve and its leisure use. For this purpose, we applied a SWOT analysis, as one of the most popular (although highly subjective) heuristic analytical tools used to analyse collected data. It allows the determination of the strengths and weaknesses of an undertaking (object), as well as its opportunities and threats, thus allowing the determination of a consistent strategy to include both internal and external factors. The SWOT analysis is routinely used in the initial stages of strategic planning as a comprehensive tool.

An analysis of the nature protection opportunities in the reserve, opposed by intense, multi-directional recreational pressure, was carried out for two scenarios:

1. Actual status, complying with the arrangements of the Protection Plan, according to which the reserve includes the entire forest area, additionally protected by the buffer zone, partly including arable land and settlements consisting of family houses.

2. Hypothetical status, assuming that the reserve is limited to separated "islands" including the most valuable natural resources, with the remaining area being a forest-park (at the same time acting as a buffer zone) adjusted for recreational purposes.

Results

The vast majority $(74 \%)$ of respondents consider Las Kabacki to be a leisure resource for inhabitants of the adjacent settlements, with less than $20 \%$ indicating its protective function as dominant. The key ways of using Las Kabacki for leisure purposes include ${ }^{4}$ : sports $(62 \%)$, meeting new people $(15 \%)$, participating in social events (27\%), getting away from noise and pollution (18\%), health and fitness $(35 \%)$. Very few respondents indicated the need to get in touch with nature $(5 \%)$ or observe nature $(3 \%)$, which are quoted as main decision-making factors

${ }^{4}$ The questionnaire allowed the selection of more than one answer. 
regarding leisure by Krzymowska-Kostrowicka (1997). Half of the respondents $(53 \%)$ are aware of the value of the reserve and the need to protect nature, but this does not impact on most of their leisure-related behaviours $(72 \%)$.

Preferred forms of leisure include: biking (42\%), "just being there" $(21 \%)$, taking a walk without a specific purpose $(24 \%)$, relaxing at "Polana Widokowa" next to the Park of Culture and Recreation (15\%) and visiting historical monuments (4\%). These results are supported by others, quoted in professional publication (Krzymowska-Kostrowicka 1997, Participation of Poles in sports and physical recreation in 2008, 2009, Janeczko, Woźnicka 2009) and research results obtained by Dębska (2010), which proved that $72 \%$ of visitors to Las Kabacki prefer sports, while $23 \%$ refrain from activity when relaxing.

The majority of respondents $(68 \%)$ do not know detailed regulations regarding reserves and the permitted forms of their use (among others, claiming the need to mark additional bike routes and improve leisure-related infrastructure) and ignore the problem of threats arising from their use of the forest $(52 \%)$. Actions taken by the City Guard protecting the reserve (unfortunately to a very limited degree ${ }^{5}$ ) are negatively assessed by respondents, who perceive them as mobbing (27\%).

Opinions expressed in direct interviews fall into four groups. The first (and largest) does not appreciate the natural value of the area or the fact that it is protected. They treat it as a good place (as good as any other) for biking, dog-walking or meeting friends. Being close to human settlements is the key quality, environmental problems being irrelevant. Most of these people do not know the environmental regulations and are unaware of the threats related to various forms of leisure. This group of users may be classified as indifferent. Their answers are closely related to those obtained from the questionnaire.

"...I do not care. The forest is close to my place, so I go there. Should I take the dog to the city centre because this area is

${ }^{5}$ This is the opinion of the authors. a reserve? I do not do anything wrong (...) A reserve in the city? A true reserve is in the mountains, or in a large forest (...) If they close this one, I will go to the park..." 6

The second group of those interviewed consists of people who identify strongly with Las Kabacki, treating it as their "second home" and considering it the best possible leisure place. This group is mainly composed of users who are aware of and respect the environmental regulations (or at least declare to do so) when entering the reserve. At the same time, they strongly object to any entrance restrictions. This group of users may be classified as involved.

"...For us, walking just for walking is of no importance. What we care about is walking just here, in this forest. It is...our second home, allows relaxing, refreshing, regaining energy. We will not let anyone take it away from us..."

The third group of users seem to attempt to eliminate the conflict of interests between the need to protect natural resources and the leisure-related needs of people. They clearly support a precise and formal determination of the forest status and strict adherence to the binding legal regulations. At the same time, they would like to make the protection more "viable" if the grounds for its execution disappear. These users may be classified as constructive and responsible.

"...Some people seem to want to prove that it is possible to have a reserve in the city. This is the case with Las Kabacki. Well, either it should remain a reserve and we need more restrictions, which are strictly observed, or let it become a park, and then it should be equipped with an appropriate infrastructure for leisure purposes, which will reduce damage to the valuable natural resources..."

"...The form of protection is what poses the problem. The reserve should not include the entire forest, but just a part of

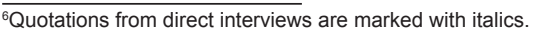

Table 2. SWOT analysis: Scenario 1 compliant with assumptions of the Draft Protection Plan for the Las Kabacki Reserve

\begin{tabular}{|c|c|}
\hline Strengths & Weaknesses \\
\hline $\begin{array}{l}\text { 1. Natural values (plant communities, old trees, natural } \\
\text { or semi-natural landscape, habitats of protected species, } \\
\text { sanctuaries, etc.). } \\
\text { 2. Values related to perception and behaviour, such as } \\
\text { scenic and relaxing features. } \\
\text { 3. Cultural values. } \\
4 . \quad \text { Scientific and educational values. }\end{array}$ & $\begin{array}{l}\text { 1. } \quad \text { Fragmentation of valuable landscape structures. } \\
\text { 2. } \quad \text { Little resistance to progressing degradation. } \\
\text { 3. } \quad \text { Progressing degradation of landscape resources and } \\
\text { values. } \\
\text { 4. } \quad \text { Randomly located recreational infrastructure. }\end{array}$ \\
\hline Opportunities & Threats \\
\hline $\begin{array}{l}\text { 1. Legal status of the area (reserve). } \\
\text { 2. } \quad \text { Draft protection plan assuming: } \\
\text { - } \quad \text { Measures aimed at improved natural value, } \\
\text { - } \quad \text { Directing traffic along selected routes, } \\
\text { - } \quad \text { Moving the recreational infrastructure to the buffer } \\
\text { zone, } \\
\text { principles, } \\
\text { - } \quad \text { Edrict adherence to and exercise of protection } \\
\text { nature. }\end{array}$ & 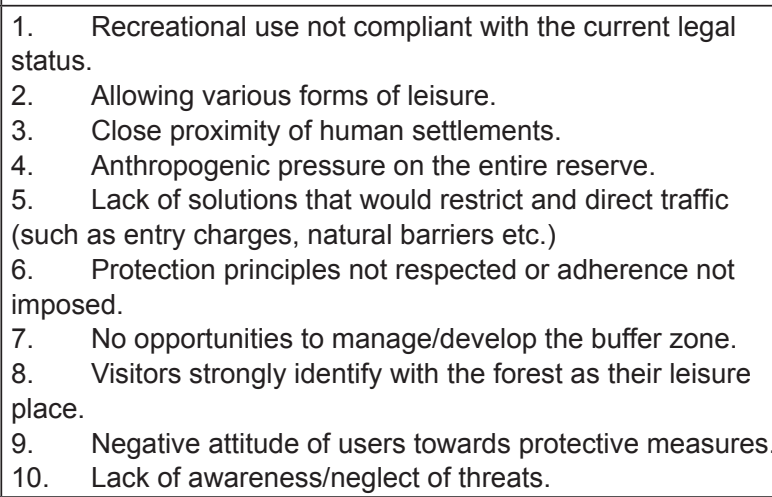 \\
\hline
\end{tabular}


Table 3. SWOT analysis: Scenario 2 assuming that the reserve is limited to certain spots and the remaining area of the forest is turned into a park and used as the buffer zone

\begin{tabular}{|c|c|}
\hline Strengths & Weaknesses \\
\hline $\begin{array}{l}\text { 1. Natural values (plant communities, old trees, natural or } \\
\text { semi-natural landscape, habitats of protected species, } \\
\text { sanctuaries, etc.). } \\
\text { 2. Values related to perception and behaviour, such as scenic } \\
\text { and relaxing features. } \\
\text { 3. Cultural values. } \\
\text { 4. Scientific and educational values. } \\
\text { 5. Rationalized leisure infrastructure. } \\
\text { 6. Degradation limited in space. }\end{array}$ & $\begin{array}{l}\text { 1. Fragmentation of valuable landscape structures. } \\
\text { 2. Little resistance to progressing degradation } \\
\text { (treading) }\end{array}$ \\
\hline Opportunities & Threats \\
\hline $\begin{array}{l}\text { 1. Legal status of the area (reserve, forest park). } \\
\text { 2. Rationalized protection measures. } \\
\text { 3. Adjusting the scope and forms of protection to the actual } \\
\text { use of the area. } \\
\text { 4. Rationalized scope and forms of access to the forest } \\
\text { (limited access to the reserve). } \\
\text { 5. Strict adherence to and exercising of protection principles. } \\
\text { 6. Anthropogenic pressure limited in space. } \\
\text { 7. Positive change in user attitudes towards protective } \\
\text { measures. }\end{array}$ & $\begin{array}{l}\text { 1. Allowing various forms of leisure. } \\
\text { 2. Close proximity of human settlements. } \\
\text { 3. New forms of anthropogenic pressure in the forest park. } \\
\text { 4. Visitors strongly identify with the forest as their leisure } \\
\text { place. }\end{array}$ \\
\hline
\end{tabular}

it, which would then preserve its natural features. The other part, excluded from protection, could be the buffer zone, adjusted for recreational purposes in a manner discouraging people from entering the protected zone..."

The quoted opinions, especially the last two, have become the starting point for developing a protection management strategy in Las Kabacki, optimized in terms of effective protection under intensive and multi-directional anthropogenic pressure, determined based on a two-scenario SWOT analysis (Table 2, 3).

The SWOT analysis carried out for the two scenarios indicates that making the protection more viable ${ }^{7}$ by limiting it to those spots where a high natural value has survived may significantly reduce external threats. The buffer zone plays a key role in this concept. Changing its characteristics from those outlined in the Protection Plan to the form of a forest park established on land excluded from the existing reserve would make it more efficient, since the zone would then constitute a natural continuation of the protected forest, without buildings or other infrastructure, and thus allow rational and purposeful development for leisure purposes, subject to the governing objective, i.e. protection. Results of research presented by Janeczko \& Woźnicka (2009) show that most visitors to urban forests spend time near the border. This buffer zone

${ }^{7}$ This is allowed by Article 13.3 of the Nature Conservation Act of 16 April 2004, stating as follows: "...The Regional Director in charge of nature protection may issue a decision (...), to reduce the reserve area or liquidate it ..."

\section{References}

Borgström, S, Cousins, SAO \& Lindborg, R 2012, 'Outside the boundary - Land use changes in the surroundings of urban nature reserves'. Applied Geography, vol. 32, no.2, pp. 350359.

Bożętka, B 2008, 'Systemy zieleni miejskiej w Polsce - ewolucja i problemy kształtowania' [Urban green areas systems in Poland - evolution and problems of management], Problemy Ekologii Krajobrazu, vol. 22: pp. 49-63. [In Polish] needs to be properly developed. At the same time, the approach would release local spatial plans from the necessity to adjust their assumptions regarding areas adjacent to the reserve.

The results of the scenario analysis need to be reinforced by further research.

\section{Summary}

Our intention as authors has been to participate in the longlasting discussion regarding the efficiency of nature protection. The problem has gained relevance in large cities, where conflict of interests regarding both function and space between the principles of nature protection and the needs of inhabitants and other forms of anthropogenic pressure is unavoidable. Principles and terms for solving the conflict should be embedded in local protection plans and in the local spatial plans for areas adjacent to natural reserves. In many cases, degradation within the protected areas has reached the level at which maintaining the protected status is unwarranted; nevertheless, it has continued. Ineffective monitoring of the efficiency of protection may be the reason for this. Anthropogenic pressure on reserves in cities may be reduced through:

- Limited access (in extreme cases),

- Adjusting the scope and forms of protection to the actual use of a given area,

- Rationalized borders and forms of access to reserves,

- Strict adherence to and exercising of the adopted protection principles.

Chmielewski, W, Dmuchowski, W \& Niekrasz, K (ed.) 1996, Zieleń Warszawy problemy i nadzieje' [Green spaces in Warsaw. Problems and hopes] Conferences materials, Warszawa - Powsin 6.09.1996, Ogród Botaniczny Polskiej Akademii Nauk, Warszawa. [In Polish]

Chojnicki, J 1991, Zróżnicowanie przestrzenne roślinności Warszawy [Spatial diversity of vegetation in Warsaw], Wydawnictwa Uniwersytetu Warszawskiego, Warszawa. [In Polish] 
Dąbrowski, W 2004, Wpływ terenów zabudowanych na środowisko przyrodnicze na przykładzie rezerwatu „Las Kabacki im. S. Starzyńskiego" [The impact of the built-up areas on the natural environment on the example of the reserve „Las Kabacki im. S. Starzyńskiego"], Master's thesis WGSR UW. Manuscript. [In Polish]

de Vries, S \& Goossen, M 2002, 'Modelling recreational visits to forests and nature areas', Urban For. Urban Green. vol.1, pp. 5-14.

Dębska, K 2010, Wybrane aspekty geoekologii wypoczynku w Lesie Kabackim [Chosen aspects of leisure geoecology in Las Kabacki], Master's thesis WGSR UW. Manuscript. [In Polish]

Faggi, A, Breuste, J, Madanes, N, Gropper, C \& Perelman, P 2011, 'Water as an appreciated feature in the landscape: a comparison of residents 'and visitors' preferences in Buenos Aires', Journal of Cleaner Production. [In Press]

General Directorate for Environmental Protection. Available from: $<$ ttp://crfop.gdos.gov.pl/CRFOP/>[13 May 2013]

Hall, CM \& Page, SJ, 2006, The Geography of Tourism and Recreation. Environment, place and space. Routledge.

Janeczko, E \& Woźnicka, M 2009, 'Zagospodarowanie rekreacyjne lasów Warszawy w kontekście potrzeb i oczekiwań mieszkańców stolicy' [Development of urban forest recreation of Warsaw in the context of the needs and expectations of the residents of the capital], Studia $i$ Materiały Centrum Edukacji Przyrodniczo-Leśnej, R.11, no. 4(23), pp. 131-139.

Jarošik, V, Konvička, M, Pyšek, P, Kadlec, T \& Beneš, J 2011, 'Conservation in a city: Do the same principles apply to different taxa?' Biological Conservation, vol. 144, no. 1, pp. 490-499.

Krzymowska-Kostrowicka, A 1997, Geoekologia turystyki $i$ wypoczynku [Geoecology of tourism and leisure], Wydawnictwo Naukowe PWN, Warszawa. [in Polsih]

Malinowska, E \& Szumacher, I 2008, 'Przestrzenne zróżnicowanie akumulacji wybranych pierwiastków w rezerwacie Las Kabacki w Warszawie' [Spatial differentiation of some elements accumulation in Kabacki Forest - natural reserve in Warsaw], Problemy Ekologii Krajobrazu, vol. 22, pp.127138. [In Polish]

Nature Conservation Act of 16 April 2004, Article 13.1
Nature Conservation Act of 16 April 2004, Article 13.3

Nature Conservation Act of 16 April 2004, Article 15.1

Nature Conservation Act of 16 April 2004, Article 15. 5

Oleksiejuk, E \& Jankowska, A (ed.) 2009, Zieleń w przestrzeni publicznej miast: naturalne bogactwo miasta [Urban greenery - natural richness of a city], Toruń, VI TechnicalScientific Conference 2009.09.21-23. Conference materials. Polskie Zrzeszenie Inżynierów i Techników Sanitarnych. Oddział, Toruń.

Opracowanie ekofizjograficzne dla studium uwarunkowań i kierunków zagospodarowania przestrzennego, Warszawa [Ecophysiography study for environmental spatial planning, Warsaw], 2006, Warszawa. Available from: <http://www. architektura.um.warszawa.pl/sites/default/files/files/ Ekofizjografia_tekst.pdf> [20 May 2012]

Ordinance of the Minister of Forestry and Wood Industry of 11 August 1980

Participation of Poles in sports and physical recreation in 2008, 2009, Central Statistical Office, Warszawa.

Piątkowska, K 1983, Zieleń i wypoczynek. Kształtowanie obiektów i zespołów usługowych [Greenery and Leisure]. Instytut Kształtowania Środowiska Warszawa. [In Polish]

Pigram, JJ \& Jenkins JM 2006, Outdoor Recreation Management, Routledge.

Plan ochrony rezerwatu „Las Kabacki im. Stefana Starzyńskiego” projekt [Draft Protection Plan for „Las Kabacki im. Stefana Starzyńskiego” Reserve], Warszawa 2010. [In Polish]

Rogowska, R 2003, Funkcje śródmiejskich rezerwatów przyrody na przykładzie rezerwatu „Las Kabacki im. S. Starzyńskiego" [Functions of the natural reserves in the city on the example of Las Kabacki im. S. Starzyńskiego reserve]. Master's thesis WGSR UW. Manuscript. [In Polish]

Seeland, K, Moser, K, Scheuthle, H \& Kaiser FG 2002, 'Public acceptance of restrictions imposed on recreational activities in the peri-urban Nature Reserve Sihlwald, Switzerland', Urban For. Urban Green. vol.1, no. 1, pp. 49-57.

Shaw, P \& Reeve, N 2008, 'Influence of a parking area on soils and vegetation in an urban nature reserve'. Urban Ecosystems, vol. 11, no. 1, pp.107-120.

Wilson, EO 1984, Biophilia, the Human Bond With Other Species. Harvard University Press. Cambridge 